\title{
Effects of Slow-release Insulin on Production, Liver Triglyceride, and Metabolic Profiles of Holsteins in Early Lactation
}

\author{
A. Hayirli, S. J. Bertics, and R. R. Grummer \\ Department of Dairy Science, \\ University of Wisconsin, Madison 53706-1284
}

\begin{abstract}
The objective of this experiment was to determine whether there is a dose of slow-release insulin (SRI) that decreases concentrations of plasma nonesterified fatty acids (NEFA) and liver triglyceride (TG) without decreasing plasma glucose concentration, dry matter intake (DMI), and milk yield. Forty-three Holsteins weighing $765 \pm 70 \mathrm{~kg}$ with body condition score of 3.29 \pm 0.25 (mean \pm SD) were fed for ad libitum consumption of the same diet from $2 \mathrm{wk}$ before parturition through $6 \mathrm{~d}$ postpartum. Cows were blocked according to actual calving date and parity and then assigned randomly to intramuscular injection of a single dose of $0,0.14,0.29$, or $0.43 \mathrm{IU}$ of SRI per kilogram of body weight (BW) on d 3 postpartum. On the day of injection, cows were fed hourly to minimize fluctuations in blood hormones and metabolites due to feed intake pattern. Blood samples were collected via jugular catheter every hour from 0 to $24 \mathrm{~h}$ and every $6 \mathrm{~h}$ from 24 to $48 \mathrm{~h}$ postinjection. Preand postinjection period liver samples were taken on $\mathrm{d}$ 2 and 5 postpartum. One cow injected with 0.29 and two cows injected with 0.43 IU of SRI per kilogram of BW could not complete the trial due to severe hypoglycemia $(<20 \mathrm{mg} / \mathrm{dl})$. Both DMI and milk yield during $\mathrm{d}$ 3 to 5 postpartum tended to increase quadratically by increasing dose of SRI. Concentrations of serum insulin and glucagon increased linearly, concentration of plasma glucose decreased linearly, and concentrations of plasma NEFA and $\beta$-hydroxybutyrate decreased quadratically from 0 to $24 \mathrm{~h}$ postinjection by increasing dose of SRI. Serum insulin concentrations remained higher in cows injected with SRI (CISRI) than in cows injected with sterile water (CISW; 0 IU of SRI/kg of BW), the quadratic effect of SRI on plasma NEFA concentration continued, and the linear effect of SRI on plasma glucose concentration diminished from 24 to 48 $\mathrm{h}$ postinjection. Concentration of hepatic TG for CISRI tended to be lower than for CISW, and increasing dose
\end{abstract}

Received October 25, 2001.

Accepted February 1, 2002.

Corresponding author: R. R. Grummer; e-mail: rgrummer@ facstaff.wisc.edu. of SRI quadratically decreased hepatic accumulation of TG. Increasing dose of SRI tended to increase concentration of hepatic glycogen (GLY) quadratically and decreased the ratio of TG to GLY quadratically. In conclusion, a low dose of SRI (0.14 IU/kg of BW) could be considered for prophylactic use against hepatic lipidosis and ketosis.

(Key words: periparturient cow, insulin, nonesterified fatty acids, liver triglyceride)

Abbreviation key: apoB = apolipoprotein B, CISRI = cows injected with slow-release insulin, $\mathbf{C I S W}=$ cows injected with sterile water, CPT I = carnitine palmitoyltransferase I, GLUT = glucose transporter, GLY = glycogen, $\mathbf{S R I}=$ slow-release insulin, $\mathbf{T G}=$ triglyceride, VLDL = very low-density lipoprotein.

\section{INTRODUCTION}

Insulin, a peptide hormone consisting of acidic and basic chains connected by disulphide bridges, is secreted from $\beta$-cells of the islets of Langerhans in the pancreas. Despite distinct differences in metabolism of nutrients and in magnitude of responses to exogenous insulin, basic structures (Hsu and Crump, 1989) and major roles (Brockman and Laarveld, 1986) of insulin in nonruminants and ruminants are similar. Insulin is an anabolic hormone and acts to preserve nutrients in their storage forms by stimulating glycogenesis, lipogenesis, and glycerol synthesis and by inhibiting gluconeogenesis, glycogenolysis, and lipolysis (Brockman and Laarveld, 1986). Insulin is also a potent regulator of feed intake and nutrient partitioning in ruminants (Laarveld et al., 1981).

Parturition and transition from gestation to lactation are under homeorhetic control. During late gestation and early lactation, lowered responsiveness and sensitivity of extra hepatic tissues to insulin (Sano et al., 1991) facilitate partitioning of nutrients for the rapidly growing fetus and mammary tissue. Due to an inability to consume adequate amounts of feed, cows mobilize body reserves to meet nutrient requirements for milk synthesis during early lactation. Increased concentrations of serum glucagon and growth hormone, plasma 
NEFA and BHBA, and liver triglyceride (TG) and decreased concentrations of serum insulin, plasma glucose, and liver glycogen (GLY) occur in periparturient cows (Herbein et al., 1985; Vazquez-Anon et al., 1994) and in cases of induced or spontaneous hepatic lipidosis and ketosis (Ballard et al., 1968; DeBoer et al., 1985).

Hepatic lipidosis and ketosis are common metabolic disorders in peripartum cows and increase predisposition to other postpartum health problems. Evidence suggests that factors involved in the etiology of hepatic lipidosis and ketosis are similar, and in both cases liver function is impaired (DeBoer et al., 1985; Drackley et al., 1992). In addition to elimination of negative energy balance, subcutaneous injection of 100 to 200 IU of protamine zinc insulin, a type of slow-release insulin (SRI), with concomitant infusion of dextrose is suggested for treatments of hepatic lipidosis (Pearson and Maas, 1990) and ketosis (Fleming, 1990). Sakai et al. (1993) showed that subcutaneous injection of $200 \mathrm{IU}$ of SRI with concomitant infusion of dextrose compared with infusion of dextrose alone for $4 \mathrm{~d}$ enhanced the effectiveness of treatment for ketosis and shortened the recovery period. As reported by Sakai et al. (1993), intravenous injection of 40 to 50 IU of insulin alone (Sato et al., 1986) or intramuscular injection of 120 to 160 IU of insulin as adjunct to infusion of dextrose (Toyoda et al., 1987) for $3 \mathrm{~d}$ were effective treatments for hyperlipoproteinemia in dairy cows.

Deetz et al. (1980) showed that intravenous injection of $4 \mathrm{IU}$ of rapid-release insulin per kilogram of $\mathrm{BW}$ increased DMI and did not decrease plasma glucose concentration in sheep. Low serum insulin concentration may promote maximal rates of gluconeogenesis and ketogenesis in the liver and lipolysis in adipose tissue during early lactation (Brockman, 1979; Holtenius, 1993). We hypothesized that there may be a dose of SRI that would decrease plasma NEFA and liver TG, without decreasing blood glucose and DMI. Therefore, our objectives were to investigate the effects of a single intramuscular injection of several doses of SRI on production and metabolic parameters of dairy cows during the first week of lactation.

\section{MATERIALS AND METHODS}

\section{Animals, Treatments, Management, and Diet}

The Research Animal and Resource Committee of the University of Wisconsin-Madison approved this experimental protocol. Forty-three Holsteins housed at the University of Wisconsin-Madison Dairy Cattle Research Center were blocked according to actual calving date and lactation number (12 entering the second lactation and 31 entering the third or greater lactation) and then assigned randomly to intramuscular injection of a single dose of $0,0.14,0.29$, or 0.43 IU of SRI per $\mathrm{kg}$ BW. Slow-release insulin $(100 \mathrm{IU} / \mathrm{ml}$; Humilin, Ultralente human insulin rDNA origin in extended zinc suspension; Eli Lilly Co., Indianapolis, IN) was injected into Musculus semitendinosus at $0800 \mathrm{~h}$ on d 3 postpartum. Cows in control group were injected with $2 \mathrm{ml}$ of sterile water.

Cows were housed in individual box stalls from $2 \mathrm{wk}$ before projected calving date through the first day of lactation and then transferred to a tie-stall facility until the end of experiment on d 6 postpartum. Body weights were measured at $1400 \mathrm{~h}$ on d 15 before projected calving date and on d 2 postpartum. Two individuals evaluated BCS on the days BW were measured using a numerical range of 1 to 5 with 0.25 unit intervals. Body weights (mean $\pm \mathrm{SD}$ ) were $765 \pm 70$ and $700 \pm 63 \mathrm{~kg}$, and BCS were $3.29 \pm 0.25$ and $3.12 \pm 0.27$ on $\mathrm{d} 12$ prepartum $(n=43 ; S D=3.7 d$ for difference between actual and projected calving dates) and d 2 postpartum $(\mathrm{n}=37)$, respectively.

Cows were fed the same diet for ad libitum consumption once daily at $0800 \mathrm{~h}$ from 2 wk before projected calving date through $6 \mathrm{~d}$ postpartum. The same diet was fed for the entire period to eliminate metabolic changes associated with diet changes. Dry matter intake was recorded daily during the experiment. To increase the likelihood that the experiment was conducted on cows that were healthy and not likely to succumb to metabolic disorders, cows were required to consume at least $6.7 \mathrm{~kg}$ of DM on d 2 postpartum. This criterion was based on a previous experiment (Hayirli et al., 2001), in which average DMI was $6.7 \mathrm{~kg}$ on d 2 postpartum and DMI increased by $11 \%$ on d 3 postpartum. Three cows did not meet this criterion and were removed from the experiment. On d 2 postpartum, DMI expressed as percentage of BW and kilogram per day were $1.82 \pm 0.6$ and $12.7 \pm 4.1(n=37$, mean $\pm \mathrm{SD})$, respectively. On d 3 postpartum, each cow was offered $130 \%$ of TMR consumed on 2 postpartum to accommodate rapidly increasing feed intake and avoid feed restriction. Feed was provided in 24 equal portions to minimize fluctuations in blood hormones and metabolites due to feed intake pattern. We did not record feed intake every hour, but none of the cows emptied the feed bunk by the end of $d 3$ postpartum.

Cows had free access to water at all times during the experiment and were released outside for approximately $3 \mathrm{~h}$ after milking at 0300 and $1500 \mathrm{~h}$, except on d 3 postpartum. Milk yields were recorded daily during the experiment. On d 2 postpartum, milk yield $(n=37$, mean $\pm \mathrm{SD}$ ) was $25.1 \pm 10.7 \mathrm{~kg}$. Measurements of heart rate and rectal temperature were obtained every $6 \mathrm{~h}$ on $\mathrm{d} 3$ and 4 postpartum for monitoring health status of cows. 
Dry matter contents of roughages and concentrate were determined weekly to adjust their proportions in the TMR. Ingredient composition of the experimental diet on a DM basis was $51.3 \%$ forage $(17.6 \%$ alfalfa silage and $82.4 \%$ corn silage) and $48.7 \%$ concentrate (54.6\% ground corn, $36.8 \%$ soybean meal $(44 \% \mathrm{CP})$, $3.8 \%$ meat and bone meal, $1.2 \%$ limestone, $0.6 \%$ magnesium oxide, $2.0 \%$ trace-mineralized salt, and $0.8 \%$ vitamin premix of vitamins $\mathrm{A}, \mathrm{D}$, and $\mathrm{K}$ ). The estimated energy value of the diet was $1.71 \mathrm{Mcal} \mathrm{NE} / \mathrm{kg}$ of $\mathrm{DM}$ (NRC, 2001). Forages and concentrates were collected biweekly, dried for $48 \mathrm{~h}$ in a $60^{\circ} \mathrm{C}$ forced-air oven, and then ground to pass through a 1-mm Wiley mill screen (Arthur H. Thomas, Philadelphia, PA). Monthly composites of forages and concentrate were analyzed for concentrations of CP using the micro-Kjeldahl method (AOAC, 1990) and NDF using the filter bag technique (Mertens, 1999). Concentrations of CP and NDF in the experimental diet $(\mathrm{n}=6$ mo, mean $\pm \mathrm{SD})$ were $15.9 \pm$ 1.1 and $22.9 \pm 2.8$, respectively.

\section{Tissue Sample Collection and Analytical Procedure}

At $1300 \mathrm{~h}$ on $\mathrm{d} 2$ postpartum, the neck area was aseptically prepared with $7.5 \%$ betadine (providine-iodine, wt/vol), 30\% ethyl alcohol (vol/vol), and 7\% iodine tincture (wt/vol) and then anesthetized locally with 5 $\mathrm{ml}$ of $2 \%$ lidocaine hydrochloride (wt/vol). About $10 \mathrm{~cm}$ of a previously autoclaved flexible tube (Tygon Microbore Tubing; Norton Performance Plastics, Akron, OH) was inserted into the jugular vein and sutured to skin for sample collection. The catheter was flushed with 10 $\mathrm{ml}$ of saline containing $10 \mathrm{IU}$ of heparin every $6 \mathrm{~h}$.

After the treatments were administered at $0800 \mathrm{~h}$ on d 3 postpartum, approximately $25 \mathrm{ml}$ of blood was collected every hour before provision of each hourly meal from 0 to $24 \mathrm{~h}$, and blood sampling was extended to every $6 \mathrm{~h}$ from 24 to $48 \mathrm{~h}$. Ten milliliters of blood was drawn into Vacutainers containing $100 \mathrm{mg}$ of potassium oxalate and $20 \mathrm{mg}$ of sodium fluoride, and samples were kept on ice. Plasma was obtained after centrifugation at $950 \times \mathrm{g}$ for $15 \mathrm{~min}$ at $4^{\circ} \mathrm{C}$, and aliquots were kept at $-20^{\circ} \mathrm{C}$ until laboratory analyses. Enzymatic assays were conducted in a micro plate reader $\left(\mathrm{EL}_{\mathrm{X}} 808\right.$ Ultra Plate Reader; Bio-Tek Instruments Inc., Los Angeles, CA) for concentrations of glucose (Raabo and Terkildsen, 1960), BHBA (Williamson et al., 1962), and NEFA (Johnson and Peters, 1993) using commercial kits (Glucose \# 510 and B-HBA kits; Sigma Chemical Co., St. Louis, MO; NEFA-C kit; Wako Fine Chemicals Industries USA, Inc., Dallas, TX).

Ten milliliters of blood was drawn into additive-free vacutainers and samples kept at room temperature. Serum was obtained after centrifugation at $2000 \times g$ for $15 \mathrm{~min}$ at $20^{\circ} \mathrm{C}$ and analyzed for concentration of insulin by radioimmunoassay (Coat-a-Count; Diagnostic Products Corp., Los Angeles, CA). An additional 3 $\mathrm{ml}$ of blood was drawn into Vacutainers containing $0.068 \mathrm{ml}$ of $\mathrm{K}_{3}$-EDTA (7.5\% wt/vol) and 1500 kallikrein inactivating units of aprotinin (ICN Biomedicals Inc., Aurora, $\mathrm{OH}$ ). Samples were protected from light and kept on ice. Serum was obtained after centrifugation at $2000 \times g$ for $15 \mathrm{~min}$ at $4^{\circ} \mathrm{C}$ and analyzed for concentration of glucagon by double-radioimmunoassay (Double Antibody Glucagon kit; Diagnostic Products Corp., Los Angeles, CA). Intra- and interassay coefficients of variations were 5.4 and $7.5 \%$ for insulin and 4.5 and $6.9 \%$ for glucagon assays, respectively.

At $1200 \mathrm{~h}$ on $\mathrm{d} 2$ and 5 postpartum, samples of liver were taken pre- and postinsulin injection by puncture biopsy between the 11th and 12th rib after aseptic preparation and administration of $10 \mathrm{ml}$ of $2.0 \%$ lidocaine. Liver samples were rinsed in saline, frozen in liquid nitrogen, and then stored at $-20^{\circ} \mathrm{C}$ until laboratory analyses. After homogenizing approximately $0.1 \mathrm{~g}$ of liver sample and isolating the total lipid content (Folch et al., 1957), the amount of TG was determined by colorimetric assay using glycerol as a standard (\# 339-11; Sigma Chemical Co., St. Louis, MO) as described by Foster and Dunn (1973). After digestion of approximately $1 \mathrm{~g}$ of liver tissue homogenate with $2 \mathrm{ml}$ of $30 \%$ $\mathrm{KOH}(\mathrm{wt} / \mathrm{vol}$ ) and precipitation with $2.4 \mathrm{ml}$ of $95 \%$ ethyl alcohol ( $\mathrm{vol} / \mathrm{vol})$, the amount of GLY was determined as described by Lo et al. (1970). A fluorometric assay (Labarca and Paigen, 1980) was used to determine hepatic DNA.

\section{Statistics}

Correlations among response variables were determined using the Corr procedure (SAS, 1998). Dry matter intake, milk yield, and liver TG and GLY data obtained on d 2 postpartum, along with blood hormone and metabolite data obtained prior to SRI injection at $0800 \mathrm{~h}$ on $\mathrm{d} 3$ postpartum, was used as covariates for statistical analyses of corresponding response variables. Covariates were excluded from models when their probability of significance was greater than 0.25 . This only occurred for parameters that were expressed as a ratio (e.g., serum insulin:glucagon). Analysis of variance was initially conducted using the Mixed procedure (SAS, 1998) as repeated measures with first-order autoregressive covariance structure in time being subplot (Littell et al., 1996). However, the large number of repeated measures resulted in a dataset that exceeded the capacity of the computer to conduct the analysis using first-order autoregressive covariance structure. Therefore, the repeated statement with first-order aut- 
oregressive covariance structure was dropped, and the conservative degree of freedom method was used (Greenhouse and Geisser, 1959). The linear model to test the effects of SRI on DMI, milk yield, and blood hormones and metabolites was as follows:

$$
\begin{gathered}
\mathrm{Y}_{\mathrm{aijk}}=\mu+\mathrm{b}_{0}+\mathrm{b}_{1}\left(\operatorname{Cov}_{\mathrm{a}}\right)+\mathrm{B}_{\mathrm{i}}+\mathrm{TRT}_{\mathrm{j}}+\text { Error A } \\
+\mathrm{t}_{\mathrm{k}}+\left(\mathrm{TRT}^{*}\right)_{\mathrm{jk}}+\text { Error B }
\end{gathered}
$$

where $\mathrm{Y}_{\mathrm{ajjk}}=$ response variable, $\mu=$ population mean, $\mathrm{b}_{0}=$ intercept, $\mathrm{b}_{1}=$ slope, $\operatorname{Cov}_{\mathrm{a}}=$ covariate $(\mathrm{a}=$ corresponding response variable), $\mathrm{B}_{\mathrm{i}}=$ block ( $\mathrm{i}=1$ to 10$), \mathrm{TRT}_{\mathrm{j}}$ $=$ treatment $(\mathrm{j}=0,0.14,0.29$, and $0.43 \mathrm{IU}$ of SRI $/ \mathrm{kg}$ $\mathrm{BW})$, Error $\mathrm{A}=$ whole plot error, $\mathrm{t}_{\mathrm{k}}=$ time $(\mathrm{k}=\mathrm{d}$ relative to parturition or $\mathrm{h}$ relative to administering treatment), $\left(\mathrm{TRT}^{*} \mathrm{t}\right)_{\mathrm{jk}}=$ treatment $\mathrm{j}$ and time $\mathrm{k}$ interaction, and Error B = subplot error. The linear model to test the effect of SRI on liver metabolites was as follows:

$$
\mathrm{Y}_{\mathrm{aij}}=\mu+\mathrm{b}_{0}+\mathrm{b}_{1}\left(\operatorname{Cov}_{\mathrm{a}}\right)+\mathrm{B}_{\mathrm{i}}+\mathrm{TRT}_{\mathrm{j}}+\mathrm{e}_{\mathrm{aij}}
$$

where $\mathrm{Y}_{\mathrm{aij}}=$ response variable, $\mu=$ population mean, $\mathrm{b}_{0}=$ intercept, $\mathrm{b}_{1}=$ slope, $\operatorname{Cov}_{\mathrm{a}}=$ covariate $(\mathrm{a}=$ corresponding response variable), $\mathrm{B}_{\mathrm{i}}=$ block $(\mathrm{i}=1$ to 10$), \mathrm{TRT}_{\mathrm{j}}=$ treatment $(j=0,0.14,0.29$, and $0.43 \mathrm{IU}$ of SRI/kg BW), and $\mathrm{e}_{\mathrm{aij}}=$ residual error.

The number of cows completing the experiment was $10,10,9$, and 8 for treatments $0,0.14,0.29$, and 0.43 IU of SRI per kg BW, respectively. A contrast to compare the mean response variables for cows injected with SRI (CISRI) versus cows injected with sterile water (CISW) and polynomial contrasts to test linear and quadratic effects of increasing dose of SRI were computed. Coefficients for polynomial contrasts were calculated as demonstrated by Carmer and Seif (1963), and probabilities of significance were generated using Satterthwaite approximation (Littell et al., 1996) because of unequal replication of treatments. Effects of SRI on response variables were considered to be significant or to have a tendency towards significance at $P \leq 0.10$ and $0.10<P \leq 0.15$, respectively.

\section{RESULTS AND DISCUSSION}

One cow injected with 0.29 and two cows injected with 0.43 IU of SRI per kilogram of BW suffered from hypoglycemic shock within 12 to $16 \mathrm{~h}$ following injection. Hypoglycemic shock was characterized by low plasma glucose $(<20 \mathrm{mg} / \mathrm{dl})$, anorexia, unconsciousness, tonic extensor spasms, coldness in the ears, excessive foamy salivation, and disturbed behavior such as pica and seizure. Within 1 to $3 \mathrm{~h}$ following intravenous infusion of $1 \mathrm{~L}$ of $50 \%$ dextrose, they recovered and started eating and ruminating, but they did not remain on experiment.

Bovine insulin was not commercially available for use in this experiment. Only enzymatically modified porcine insulin and recombinant human insulin were available. However, insulin produced by different species has similar structure. Threonine located in position 30 of the $\mathrm{B}$ chain in human insulin $\left(\mathrm{C}_{257} \mathrm{H}_{383} \mathrm{~N}_{65} \mathrm{O}_{77} \mathrm{~S}_{6}\right.$, MW of 5807.7) is replaced with Ala in porcine $\left(\mathrm{C}_{256} \mathrm{~N}_{381} \mathrm{~N}_{65} \mathrm{O}_{76} \mathrm{~S}_{6}\right.$, MW of 5777.6) and bovine insulin $\left(\mathrm{C}_{254} \mathrm{H}_{377} \mathrm{~N}_{65} \mathrm{O}_{75} \mathrm{~S}_{6}, \mathrm{MW}\right.$ of 5733.6). Also, The and Ile in positions 8 and 10 of the A chain in human insulin are replaced with Ala and Val in bovine insulin (Hsu and Crump, 1989).

\section{Effect of Slow-release Insulin on Production and Health Parameters}

Feed intake. Average DMI (kg/d) for CISW and CISRI during $\mathrm{d} 3$ to 5 postpartum was not different ( $P$ $<0.74$ [Table 1]). However, increasing dose of SRI tended to increase DMI $(\mathrm{kg} / \mathrm{d})$ quadratically $(P<0.13)$. We cannot explain the quadratic response; however, cows did not increase feed intake to overcome hypoglycemia. There were no effects of treatment on DMI expressed as a percentage of BW (Table 1). Our data and those of others (Baile and Mayer, 1968; Deetz and Wangsness, 1980; Deetz and Wangsness, 1981) indicate that the effects of insulin on feed intake of ruminants has been variable. Subcutaneous injections of goats with 100 and $160 \mathrm{IU}$ of SRI for a day (short-term) and $80 \mathrm{IU}$ for $14 \mathrm{~d}$ (long-term) caused hyperinsulinemia and hypoglycemia without altering DMI (Baile and Mayer, 1968). Deetz and Wangsness (1981) reported that five intravenous injections of 6 IU of rapid-release insulin per kilogram of BW during $24 \mathrm{~h}$ decreased DMI by $8.5 \%$ compared with intravenous injections of saline in sheep. In another study using sheep, Deetz and Wangsness (1980) reported that intravenous injection of a very high dose of rapid-release insulin (2000 IU/kg of BW) caused severe hypoglycemia without affecting DMI, whereas intravenous injection of a moderate dose of rapid-release insulin (6 IU/kg of BW) decreased DMI without causing hypoglycemia. Increasing doses of rapid-release insulin $(0,2,4$, and $6 \mathrm{IU} / \mathrm{kg}$ of BW) via intraportal delivery linearly decreased DMI in sheep (Deetz et al., 1980). In contrast, increasing doses of rapid-release insulin via intrajugular delivery quadratically increased DMI; DMI was the maximum in sheep injected with 4 IU per kg BW (Deetz et al., 1980). These studies suggest that the effect of insulin on feed intake of ruminant depends on type or dose of insulin or means of delivery or a combination of both. Moreover, it appears that 
Table 1. Effects of a single dose of slow-release insulin on production and health parameters of Holsteins during the first week of lactation.

\begin{tabular}{|c|c|c|c|c|c|c|c|c|}
\hline \multirow[b]{2}{*}{ Response variable ${ }^{3}$} & \multicolumn{4}{|c|}{ Insulin dose, IU/kg BW ${ }^{1}$} & \multirow[b]{2}{*}{ SEM } & \multicolumn{3}{|c|}{ Significance of insulin effect $(P>\mathrm{F})^{2}$} \\
\hline & 0 & 0.14 & 0.29 & 0.43 & & Insulin & Linear & Quadratic \\
\hline DMI, kg/d ${ }^{4}$ & 15.1 & 16.6 & 15.6 & 14.3 & 0.9 & 0.74 & 0.49 & 0.13 \\
\hline DMI, $\%$ of $\mathrm{BW}^{5}$ & 2.15 & 2.39 & 2.20 & 2.11 & 0.12 & 0.59 & 0.65 & 0.18 \\
\hline Milk, kg/d & 30.1 & 34.7 & 31.9 & 29.3 & 2.6 & 0.59 & 0.72 & 0.15 \\
\hline Heart rate, beats $/ \mathrm{min}^{5}$ & 76.5 & 75.0 & 78.8 & 74.6 & 1.6 & 0.84 & 0.87 & 0.48 \\
\hline Rectal temperature, ${ }^{\circ} \mathrm{C}^{6,7}$ & 38.9 & 38.9 & 38.8 & 38.8 & $<0.1$ & 0.29 & 0.12 & 0.85 \\
\hline
\end{tabular}

\footnotetext{
${ }^{1}$ Data were covariately adjusted with the least squares means. Treatments were applied at $0800 \mathrm{~h}$ on $\mathrm{d}$ 3 postpartum.

${ }^{2}$ Probability values were Satterthwaite approximates. Contrasts: Insulin = cows intramuscularly injected with sterile water versus cows intramuscularly injected with slow-release insulin; Linear = linear effect of increasing doses of slow-release insulin; Quadratic = quadratic effect of increasing doses of slow-release insulin.

${ }^{3}$ Dry matter intake and milk yield were recorded on $\mathrm{d} 3,4$, and 5 postpartum, and heart rate and rectal temperature were measured every $6 \mathrm{~h}$ on $\mathrm{d} 3$ and 4 postpartum.

${ }^{4}$ Time effect $(P<0.02)$

${ }^{5}$ Time effect $(P<0.01)$.

${ }^{6}$ Time effect $(P<0.001)$.

${ }^{7}$ Treatment $\times$ time effect $(P<0.11)$.
}

ruminants do not overcome hypoglycemia by increasing feed intake.

Milk yield. Although average milk yield during d 3 to 5 postpartum did not differ between CISW and CISRI $(P<0.59)$, increasing dose of SRI tended to increase milk yield quadratically $(P<0.15$ [Table 1$])$. Unlike DMI, milk yield responses to exogenous insulin are consistent in the literature. Intramuscular injections of cows with 0.2 to 0.6 IU (Kronfeld et al., 1963) and 0.35 IU (Schmidt, 1966) of rapid-release insulin per kilogram of BW depressed both milk and lactose yields. Milk yield was restored following infusion of dextrose, suggesting that depression of milk yield is due to hypoglycemia, not a direct effect of insulin per se (Kronfeld et al., 1963; Schmidt, 1966). Insulin partitions nutrients toward more insulin responsive tissues (i.e., adipose and muscle tissues) for storage. As a result, exogenous insulin may lead to decreased availability of glucose for mammary tissue because insulin does not regulate uptake of glucose through facilitative glucose transporter (GLUT) 1 that predominates in the mammary gland (Laarveld et al., 1981; Zhao et al., 1993). In this study, the quadratic effect of increasing dose of SRI on milk yield (Table 1) could be related to the quadratic increase in DMI $(r=0.40, P<0.02)$, suggesting that the effect of insulin on milk synthesis was indirect.

Heart rate and rectal temperature. Heart rates tended to change during $\mathrm{d} 3$ to 4 postpartum (time effect, $P<0.11$ [Table 1]). There were no effects of insulin on heart rates. Potassium is required for transport of glucose and insulin and plays a role in regulation of heart rhythm (Genuth, 1993). Hypokalemia is an adverse effect of administering excessive insulin during diabetic ketoacidosis and can cause an inversion of the $\mathrm{T}$ wave and a prolongation of the $\mathrm{Q}$ to $\mathrm{T}$ interval during an electrocardiogram (Goth, 1968). In this study, mean heart rate (76 beats/min) was close to the upper level of the normal range ( 80 beats/min).

There was a diurnal variation in rectal temperature (time effect, $P<0.001$ [Table 1]). Although there was no difference in rectal temperatures between CISW and CISRI $(P<0.29)$, increasing dose of SRI tended to decrease rectal temperature linearly $(P<0.12)$. However, mean differences were extremely small and probably not of biological significance.

\section{Effect of Slow-release Insulin on Blood Parameters}

Serum insulin concentration. Serum insulin concentrations for CISW remained relatively constant during 0 to $24 \mathrm{~h}$ following injection (Figure 1 ). Serum insulin concentrations for cows injected with a single dose of 0.14, 0.29, and 0.43 IU of SRI per kilogram of BW increased by 3.3, 7.0, and 10.2 times during 0 to $12 \mathrm{~h}$ postinjection, respectively, and then gradually decreased. Concentrations were still 1.4, 1.6, and 2.3 times greater than preinjection concentrations at $24 \mathrm{~h}$ following injection, respectively (time effect, $P<0.003$ and treatment $\times$ time interaction, $P<0.07$ [Figure 1]). Average serum insulin concentration for CISRI was greater than for CISW $(P<0.0001)$, and increasing dose of SRI linearly increased serum insulin concentration $(P<0.0001)$ during 0 to $24 \mathrm{~h}$ following injection (Table 2). Moreover, serum insulin concentrations for CISRI remained higher than for CISW $(P<0.08)$, and increasing dose of SRI quadratically increased serum insulin 


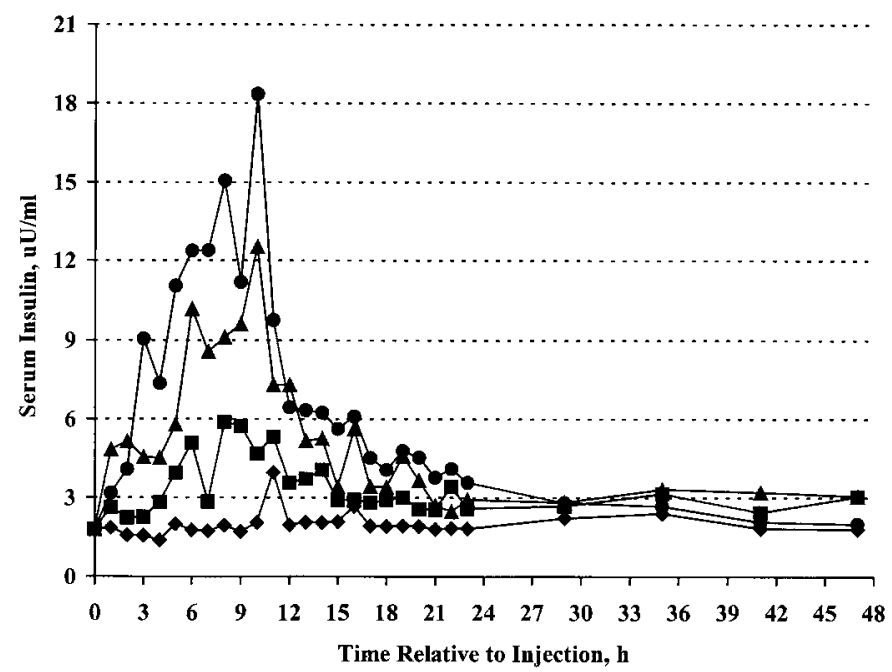

Figure 1. Serum insulin concentrations for cows intramuscularly

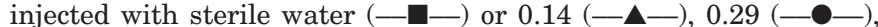
or 0.43 (- - ) IU of slow-release insulin per kilogram of BW at $0800 \mathrm{~h}$ on $\mathrm{d} 3$ postpartum. Pooled standard errors were 1.36 and 0.46 for data obtained during 0 to $24 \mathrm{~h}$ and 24 to $48 \mathrm{~h}$ following injection, respectively. Probabilities of significance for effects of time and treatment $\times$ time interaction during 0 to $24 \mathrm{~h}$ were $P<0.003$ and $P$ $<0.07$ and during 24 to $48 \mathrm{~h}$ postinjection were $P<0.24$ and $P$ $<0.86$, respectively. concentration $(P<0.04)$ during 24 to $48 \mathrm{~h}$ following injection (Table 2).

Duration and promptness of insulin actions vary depending on the method of delivery and type of insulin (Reynolds, 1989). According to pharmacokinetics, insulin is categorized as rapid-release (crystalline or regular), intermediate-release (Isophane and Lente), and slow-release (protamine zinc insulin or UltraLente) insulin (Drug Facts and Comparisons, 2000). In humans, serum concentrations of insulin from subcutaneous delivery of short-, intermediate-, and slow-release insulin peak from 0.5 to $1.5,4$ to 12 , and 10 to $24 \mathrm{~h}$ following injection, respectively, and the effects of insulin last for 7, 24, and $36 \mathrm{~h}$, respectively (Reynolds, 1989). Time to achieve peak serum insulin concentration and to reach basal serum insulin concentration (the duration of action) were shorter for CISRI compared with those measured in humans administered SRI subcutaneously (Reynolds, 1989). Due to the enriched vascular network around muscle tissue compared to adipose tissue, intramuscular injection decreases time between injection and effectiveness of insulin (Reynolds, 1989).

Plasma glucose concentration. Similar to serum insulin, plasma glucose concentrations for CISW remained relatively constant during 0 to $24 \mathrm{~h}$ following injection (Figure 2). However, plasma glucose concen-

Table 2. Effects of a single dose of slow-release insulin on blood metabolites and hormones of Holsteins during the first week of lactation.

\begin{tabular}{|c|c|c|c|c|c|c|c|c|}
\hline \multirow[b]{2}{*}{ Response variable ${ }^{3}$} & \multicolumn{4}{|c|}{ Insulin dose, IU/kg BW ${ }^{1}$} & \multirow[b]{2}{*}{ SEM } & \multicolumn{3}{|c|}{ Significance of insulin effect $(P>\mathrm{F})^{2}$} \\
\hline & 0 & 0.14 & 0.29 & 0.43 & & Insulin & Linear & Quadratic \\
\hline \multicolumn{9}{|l|}{$0-24 \mathrm{~h}$} \\
\hline Insulin, $\mu \mathrm{U} / \mathrm{ml}$ & 2.0 & 3.5 & 5.7 & 7.6 & 0.7 & 0.0001 & 0.0001 & 0.81 \\
\hline Glucose, mg/dl & 47.5 & 42.3 & 35.8 & 36.7 & 1.7 & 0.0001 & 0.0001 & 0.12 \\
\hline Glucose:insulin & 0.27 & 0.13 & 0.08 & 0.07 & 0.02 & 0.0001 & 0.0001 & 0.002 \\
\hline Glucagon, pg/ml & 93.2 & 108.4 & 103.1 & 111.2 & 7.1 & 0.08 & 0.12 & 0.55 \\
\hline Insulin:glucagon & 0.13 & 0.26 & 0.54 & 0.55 & 0.08 & 0.0006 & 0.0001 & 0.50 \\
\hline NEFA, $\mu \mathrm{Eq} / \mathrm{L}$ & 576 & 512 & 539 & 643 & 41 & 0.89 & 0.28 & 0.05 \\
\hline $\mathrm{BHBA}, \mathrm{mg} / \mathrm{dl}$ & 11.0 & 7.9 & 8.7 & 8.6 & 0.7 & 0.003 & 0.04 & 0.03 \\
\hline \multicolumn{9}{|l|}{$24-48 \mathrm{~h}$} \\
\hline Insulin, $\mu \mathrm{U} / \mathrm{ml}$ & 2.0 & 2.8 & 3.1 & 2.4 & 0.3 & 0.08 & 0.33 & 0.04 \\
\hline Glucose, mg/dl & 48.4 & 49.9 & 48.1 & 44.7 & 2.0 & 0.68 & 0.18 & 0.24 \\
\hline NEFA, $\mu \mathrm{Eq} / \mathrm{L}$ & 576 & 545 & 565 & 808 & 56 & 0.26 & 0.01 & 0.02 \\
\hline Glucose:insulin & 0.23 & 0.18 & 0.15 & 0.17 & 0.02 & 0.02 & 0.05 & 0.13 \\
\hline
\end{tabular}

\footnotetext{
${ }^{1}$ Data were covariately adjusted with the least squares means. Treatments were applied at 0800 on $\mathrm{d} 3$ postpartum.

${ }^{2}$ Probability values were Satterthwaite approximates. Contrasts: Insulin = cows intramuscularly injected with sterile water versus cows intramuscularly injected with slow-release insulin; Linear = linear effect of increasing doses of slow-release insulin; Quadratic = quadratic effect of increasing doses of slow-release insulin.

${ }^{3}$ Statictical analyses for measurements obtained during 0 to 24 and 24 to $48 \mathrm{~h}$ were computed separately. Serum insulin, plasma glucose, and plasma NEFA concentrations were measured every hour during 0 to $24 \mathrm{~h}$ and every $6 \mathrm{~h}$ during 24 to $48 \mathrm{~h}$ following injection. Plasma BHBA and serum glucagon concentrations were measured at 2, 4, 6, 8, 10,12, 18, and $24 \mathrm{~h}$ following injection. Glucose:insulin = mmol:pmol. Insulin:glucagon $=$ pmol:pmol.
} 


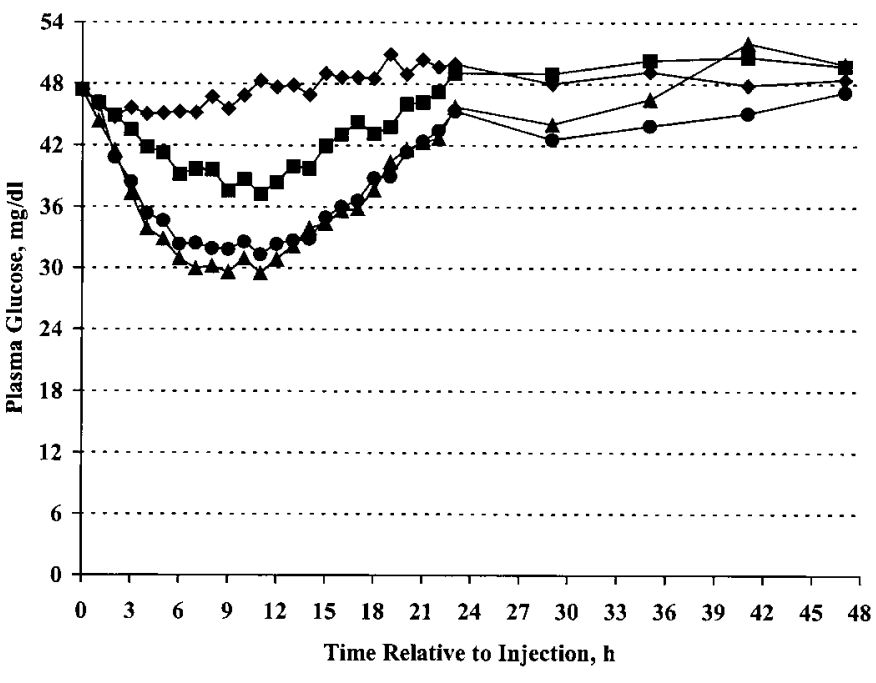

Figure 2. Plasma glucose concentrations for cows intramuscularly

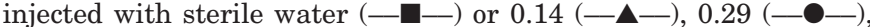
or 0.43 (- - ) IU of slow-release insulin per kilogram of BW at $0800 \mathrm{~h}$ on $\mathrm{d} 3$ postpartum. Pooled standard errors were 2.16 and 2.17 for data obtained during 0 to $24 \mathrm{~h}$ and 24 to $48 \mathrm{~h}$ following injection, respectively. Probabilities of significance for effects of time and treatment $\times$ time interaction during 0 to $24 \mathrm{~h}$ were $P<0.0001$ and $P$ $<0.07$ and during 24 to $48 \mathrm{~h}$ postinjection were $P<0.02$ and $P$ $<0.08$, respectively.

trations for cows injected with a single dose of 0.14 , 0.29 , and $0.43 \mathrm{IU}$ of SRI per kilogram of BW decreased by 21,38 , and $35 \%$, respectively, during 0 to $12 \mathrm{~h}$ postinjection and then gradually increased and reached 103 , 97 , and $96 \%$ of preinjection concentration at $24 \mathrm{~h}$ following injection, respectively $(P<0.0001$ for time effect, $P<0.07$ for treatment $\times$ time interaction [Figure 2]). Average plasma glucose concentration for CISW was higher than for CISRI $(P<0.0001)$; plasma glucose concentration decreased linearly $(P<0.0001)$ and tended to decrease quadratically $(P<0.12)$ by increasing dose of SRI during 0 to $24 \mathrm{~h}$ following injection (Table 2). There were effects of time $(P<0.02)$ and treatment $\times$ time interaction $(P<0.08)$ on plasma glucose concentration during 24 to $48 \mathrm{~h}$ following injection (Figure 2). However, mean plasma glucose concentration did not differ between CISRI and CISW, and both the linear and quadratic effects of increasing SRI dose during 0 to $24 \mathrm{~h}$ were diminished during 24 to $48 \mathrm{~h}$ following injection (Table 2). Average molar ratio of plasma-glucose-to-serum-insulin for CISW was greater than for CISRI during both 0 to $24 \mathrm{~h}(P<0.0001)$ and 24 to $48 \mathrm{~h}(P<0.02)$ following injection. Increasing dose of SRI also decreased molar ratio of plasma glucose to serum insulin during both 0 to $24 \mathrm{~h}$ (linear effect, $P<$ 0.0001 and quadratic effect, $P<0.002$ ) and 24 to $48 \mathrm{~h}$ (linear effect, $P<0.05$ and quadratic effect, $P<0.13$ ) postinjection (Table 2).
Similar to serum insulin, feeding every hour maintained plasma glucose concentrations for CISW (Figure 2 , Table 2). Although serum insulin concentrations reached basal level by $24 \mathrm{~h}$ postinjection and there were no differences in plasma glucose concentrations between CISRI and CISW during 24 to 48 postinjection, the lower ratio of plasma glucose to serum insulin concentrations for CISRI than for CISW during 24 to 48 $\mathrm{h}$ following injection (Table 2) suggests that there was a carryover effect of SRI. Baile and Mayer (1968) showed that subcutaneous injection of SRI similar to the low and medium doses tested in the present study caused hypoglycemia $(<15 \mathrm{mg} / \mathrm{dl}$ in serum) in goats. Intravenous injection of rapid-release insulin $(6 \mathrm{IU} / \mathrm{kg}$ of BW) decreased plasma glucose concentration in sheep (Deetz and Wangsness, 1980). Insulin facilitates entry of glucose into cells by speeding up the basal rate of exocytosis and slowing down the basal rate of endocytosis of GLUT 2 in the liver and pancreas and GLUT 4 in adipose and muscle tissues (Katzung, 1995). The hypoglycemic effect of insulin may be the consequence of increased oxidation of glucose by extrahepatic tissues, decreased production of glucose by hepatic tissue via inhibition of gluconeogenesis and glycogenolysis, and increased storage of glucose by hepatic and extrahepatic tissues via stimulation of glycogenesis, or a combination of any of the above (Brockman and Laarveld, 1986).

Serum glucagon concentration. Serum glucagon concentrations for CISW decreased by $15 \%$ during 0 to $24 \mathrm{~h}$ postinjection and then increased to $95 \%$ of preinjection concentrations at $24 \mathrm{~h}$ following injection (Figure 3 ). When cows were injected with a single dose of 0.14 , 0.29 , and $0.43 \mathrm{IU}$ of SRI per kilogram of BW, serum glucagon concentrations increased by 11,12 , and $19 \%$, respectively, during 0 to $12 \mathrm{~h}$ postinjection and then gradually decreased to 98,95 , and $88 \%$ of preinjection concentrations by $24 \mathrm{~h}$ following injection, respectively (time effect, $P<0.08$ and treatment $\times$ time interaction, $P<0.15$ [Figure 3]). Mean serum glucagon concentration for CISW was lower than for CISRI $(P<0.08)$, and increasing dose of SRI tended to increase serum glucagon concentrations linearly $(P<0.12)$ during 0 to $24 \mathrm{~h}$ following injection (Table 2). Moreover, average molar ratio of insulin-to-glucagon for CISRI was greater than for CISW $(P<0.0006)$, and increasing dose of SRI linearly increased this ratio $(P<0.0001$ [Table 2] $)$ during 0 to $24 \mathrm{~h}$ following injection.

Insulin and glucagon usually act reciprocally to regulate metabolism, and their concentrations in blood change reciprocally in nonruminants (Genuth, 1993). In contrast, because of reliance on gluconeogenesis and glycogenolysis for glucose production, glucagon concentration does not change dramatically under normal 


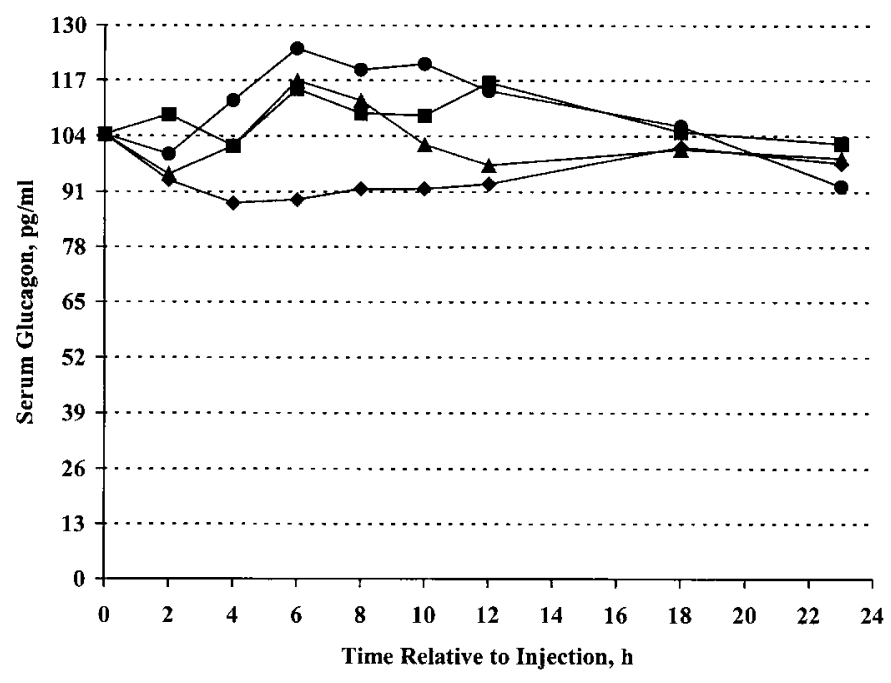

Figure 3. Serum glucagon concentrations for cows intramuscularly injected with sterile water (—-) or 0.14 (———), 0.29 (- - - ) , or 0.43 (- - ) IU of slow-release insulin per kilogram of BW at $0800 \mathrm{~h}$ on $\mathrm{d} 3$ postpartum. Pooled standard error was 8.49 and probabilities of significance for effects of time and treatment $\times$ time interaction during 0 to $24 \mathrm{~h}$ postinjection were $P<0.08$ and $P$ $<0.15$, respectively.

physiological conditions in ruminants (Herbein et al., 1985). However, increased serum glucagon concentrations were shown during spontaneous ketosis (Brockman, 1979), experimentally induced ketosis by feed deprivation (Drackley, 1992), and early lactation (Hayirli, 2001), when serum insulin concentrations were low, suggesting that cows may meet the energy demand for milk synthesis in part by pancreatic secretion of glucagon. In the present study, increased serum glucagon concentrations by SRI (Figure 3; Table 2) could be related to stimulation of glucagon secretion, probably through insulin's hypoglycemic effect (Genuth, 1993).

Plasma nonesterified fatty acid concentration. Sampling time affected plasma NEFA concentrations in a sine-wave manner during both 0 to $24 \mathrm{~h}$ and 24 to $48 \mathrm{~h}$ following injection (time effect for both phases, $P$ $<0.007$ and $P<.001$ [Figure 4]). Increasing dose of SRI did not alter the magnitude of diurnal effects on plasma NEFA concentrations during both 0 to $24 \mathrm{~h}$ (treatment $\times$ time interaction, $P<0.26$ ) and 24 to $48 \mathrm{~h}$ (treatment $\times$ time interaction, $P<0.28$ ) postinjection (Figure 4 ). There were no differences in mean plasma NEFA concentrations between CISRI and CISW during 0 to $24 \mathrm{~h}$ $(P<0.89)$ and 24 to $48 \mathrm{~h}(P<0.26)$ following injection (Table 2). Increasing dose of SRI quadratically decreased mean plasma NEFA concentrations during 0 to $24 \mathrm{~h}(P<0.05)$ and 24 to $48 \mathrm{~h}(P<0.02)$ following injection (Table 2).

Although animals were fed every hour to minimize fluctuation in blood hormones and metabolites, diurnal

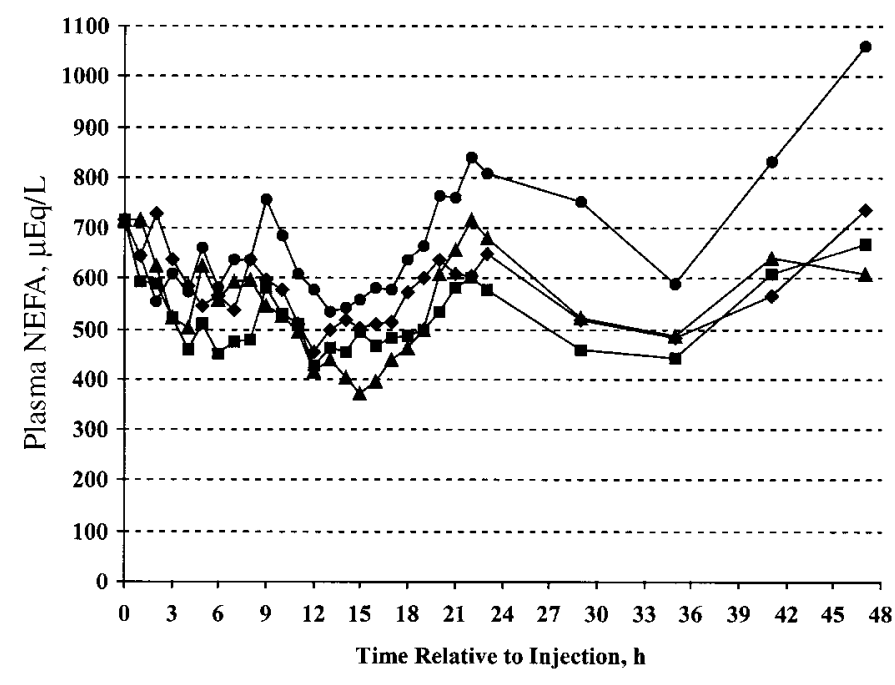

Figure 4. Plasma NEFA concentrations for cows intramuscularly injected with sterile water (- - ) or 0.14 (一- -0.29 (一 $-\mathbf{\Delta})$, or 0.43 (- - ) IU of slow-release insulin per kilogram of BW at 0800 $\mathrm{h}$ on d 3 postpartum. Pooled standard errors were 61.03 and 73.69 for data obtained during 0 to $24 \mathrm{~h}$ and 24 to $48 \mathrm{~h}$ following injection, respectively. Probabilities of significance for effects of time and treatment $\times$ time interaction during 0 to $24 \mathrm{~h}$ were $P$ $<0.007$ and $P<0.26$ and during 24 to $48 \mathrm{~h}$ postinjection were $P$ $<0.001$ and $P<0.24$, respectively.

effects on plasma NEFA were as profound as or more profound than the antilipolytic effects of insulin. Increases in plasma NEFA concentrations coincided with times of milking, which may reflect adrenalin secretion during cow movement. Diurnal effects on plasma NEFA concentrations were observed during late gestation, early lactation, induced ketonemia, and following recovery from induced ketonemia (DeBoer et al., 1985). Insulin enhances fatty-acid synthesis and storage of fatty acids in the form of TG in adipose tissue through stimulation of lipogenic enzymes (lipoprotein lipase, acetylCoA carboxylase, and fatty acid synthase). Additionally, insulin suppresses lipolysis by lowering the level of cAMP and inhibiting activities of protein kinase A and hormone sensitive-lipase (Brockman, 1979; Genuth, 1993). Failure to obtain a linear decrease of plasma NEFA could have been related to the quadratic increase in DMI as dose of SRI was increased ( $\mathrm{r}=-0.67$ between NEFA and DMI, $P<0.0001)$. Increasing blood insulin may cause down regulation of insulin receptors (Garvey et al., 1986). Additionally, increased plasma NEFA concentration may adversely affect physiological action of insulin by disabling insulin receptors and compromising translocation of GLUT 4 (Van Putten et al., 1985; Van Epps-Fung et al., 1997). During early lactation, nutritional and metabolic conditions to support lactation favor increased plasma NEFA and ketones as a result of lipolysis and ketogenesis, which may also lead 


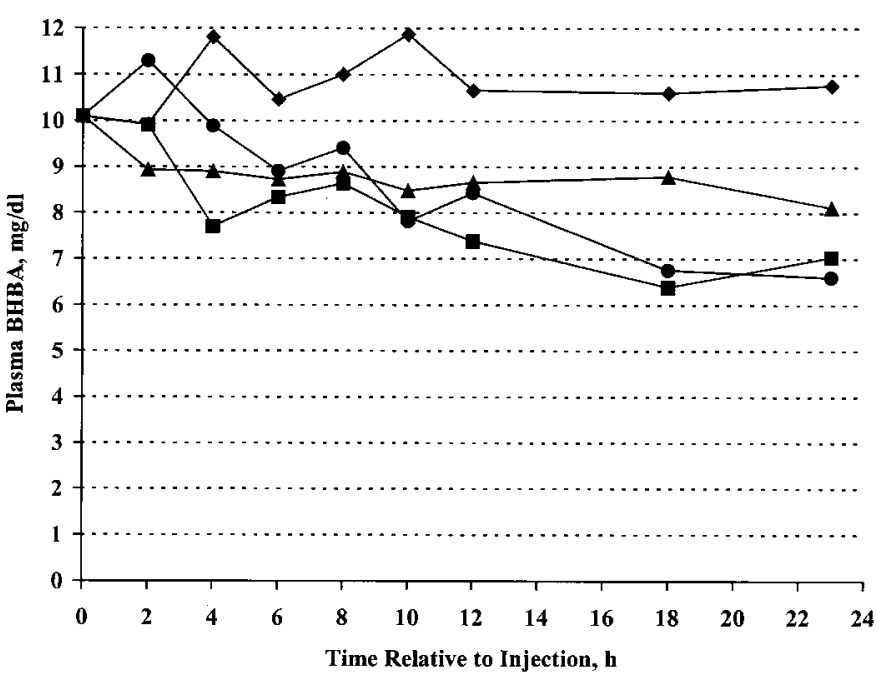

Figure 5. Plasma $\beta$-hydroxybutyrate concentrations for cows intramuscularly injected with sterile water (- -) or 0.14 (-口-), 0.29 (一 - - ) , or 0.43 (一- - IU of slow-release insulin per kilogram of BW at $0800 \mathrm{~h}$ on d 3 postpartum. Pooled standard error was 0.96 and probabilities of significance for effects of time during 0 to $24 \mathrm{~h}$ postinjection was $P<0.07$.

to lowered adipose tissue responsiveness to insulin (Holtenius, 1993).

Plasma $\beta$-hydroxybutyrate concentration. Plasma BHBA concentrations for CISW were relatively constant during 0 to $24 \mathrm{~h}$ following injection (Figure 5). When cows were injected with $0.14,0.29$, and $0.43 \mathrm{IU}$ of SRI per kilogram of BW, plasma BHBA concentrations decreased continuously to 30,20 , and $35 \%$ of preinjection concentrations by $24 \mathrm{~h}$ postinjection, respectively (time effect, $P<0.07$ [Figure 5]). During 0 to $24 \mathrm{~h}$ following injection, average plasma BHBA concentration for CISRI was lower than for CISW $(P<0.003)$, and increasing dose of SRI linearly $(P<0.04)$ and quadratically $(P<0.03)$ decreased plasma BHBA concentrations (Table 2).

Excessive uptake of NEFA by the liver results partially in fatty-acid oxidation to ketones (Cadorniga-Valino et al., 1997). Plasma NEFA concentrations decreased quadratically, whereas plasma BHBA decreased both linearly and quadratically with increasing SRI dose (Table 2). Moreover, there was a positive correlation between concentrations of plasma NEFA and BHBA ( $\mathrm{r}=0.52, P<0.002)$. Brockman (1979) summarized direct and indirect antiketogenic effects of insulin, which include decreasing liver NEFA uptake through stimulating lipogenesis and inhibiting lipolysis in adipose tissue, enhancing peripheral tissue ketone utilization, and altering enzyme activities and availability of substrates that are involved in ketogenesis in the liver. Insulin decreases activity of carnitine palmitoyltransf- erase I (CPT I) and increases affinity of CPT I for malonyl-CoA (Grantham and Zammit, 1988). In the liver, this enzyme is a potent regulator of translocation of long-chain fatty acids from the cytoplasm into the mitochondria, where they partition for esterification and oxidation (Genuth, 1993). Moreover, insulin's inhibitory effect on ketogenesis is also related to its stimulatory effect on activity of acetyl-CoA carboxylase or formation of malonyl-CoA that inhibits activity of CPT I (Zammit, 1996).

\section{Effect of Slow-release Insulin on Liver Metabolites}

Liver triglyceride. During the pre- and postinjection period, CIWS deposited more TG in the liver than CISRI $(P<0.10$, [Table 3]). Increasing dose of SRI quadratically decreased the percentage increase in liver TG between $\mathrm{d} 2$ and 5 postpartum $(P<0.02)$. On d 5 postpartum, average liver TG concentration for CISRI tended to be lower than for CISW $(P<0.11)$. Liver TG values were lower than those previously reported (15$25 \mu \mathrm{g}$ TG $/ \mu \mathrm{g}$ DNA, [Hartwell et al., 2000]); perhaps effects of SRI would have been more dramatic in cows with more extensive TG accumulation after calving. Nonesterified fatty acids mobilized from adipose tissue are the primary precursors for hepatic TG. Major factors causing hepatic lipidosis are suggested to be increased supply of long-chain fatty acids and impairment of TG export as very low-density lipoprotein (VLDL) transport (Kleppe et al., 1988). Depression in DMI and consequently decreased serum insulin and increased plasma NEFA concentrations around parturition coincide with increased TG in the liver. Hepatic lipidosis may become significant when the export of TG as VLDL from the liver cannot keep pace with increased NEFA uptake and TG synthesis by the liver (Grummer, 1993). Therefore, limiting fat mobilization from adipose tissue and improving TG export ability of the liver are essential strategies for alleviation of hepatic lipidosis.

Effects of insulin on synthesis and degradation of apolipoprotein B (apoB) and on export of TG as VLDL from the liver are conflicting. Inhibitory effects of insulin on hepatic VLDL output and apoB synthesis were demonstrated in diabetic humans (Gibbons, 1990). A study conducted in rats (Chirieac et al., 2000) supports that insulin suppresses hepatic VLDL and apoB secretions, whereas another study conducted in rats (Satoh et al., 1987) supports that insulin enhances TG secretion rate. Bremmer et al. (2000) provided evidence that activity of bovine microsomal TG transfer protein that is required for assembly and secretion of apoB containing VLDL is not affected by insulin.

Increasing the dose of SRI quadratically decreased concentrations plasma NEFA (Table 2) and liver TG 
Table 3. Effects of a single dose of slow-release insulin on liver metabolites of Holsteins during the first week of lactation.

\begin{tabular}{|c|c|c|c|c|c|c|c|c|}
\hline \multirow[b]{2}{*}{ Response variable } & \multicolumn{4}{|c|}{ Insulin dose, IU/kg BW ${ }^{1}$} & \multirow[b]{2}{*}{ SEM } & \multicolumn{3}{|c|}{ Significance of insulin effect $(P>\mathrm{F})^{2}$} \\
\hline & 0 & 0.14 & 0.29 & 0.43 & & Insulin & Linear & Quadratic \\
\hline \multicolumn{9}{|l|}{ Triglyceride (TG) } \\
\hline $\mathrm{d} 5$ minus $\mathrm{d} 2, \mu \mathrm{g} / \mu \mathrm{g}$ DNA & 4.5 & -0.6 & 1.2 & 1.2 & 2.0 & 0.10 & 0.34 & 0.21 \\
\hline Relative change, $\%$ & 38.0 & -6.0 & 21.0 & 40.0 & 16.0 & 0.17 & 0.93 & 0.02 \\
\hline $\mathrm{d} 5, \mu \mathrm{g} / \mu \mathrm{g} \mathrm{DNA}$ & 16.9 & 11.8 & 13.5 & 13.7 & 2.1 & 0.11 & 0.38 & 0.23 \\
\hline \multicolumn{9}{|l|}{ Glycogen (GLY) } \\
\hline $\mathrm{d} 5$ minus $\mathrm{d} 2 \mu \mathrm{g} / \mu \mathrm{g}$ DNA & 2.5 & 6.2 & 6.0 & 2.1 & 2.5 & 0.44 & 0.96 & 0.14 \\
\hline Relative change, $\%$ & 160.0 & 122.0 & 181.0 & 108.0 & 72.0 & 0.75 & 0.79 & 0.80 \\
\hline $\mathrm{d} 5, \mu \mathrm{g} / \mu \mathrm{g} \mathrm{DNA}$ & 9.6 & 14.2 & 13.5 & 8.9 & 2.5 & 0.41 & 0.93 & 0.08 \\
\hline TG:GLY & 4.7 & 1.3 & 2.0 & 5.6 & 2.0 & 0.47 & 0.84 & 0.08 \\
\hline
\end{tabular}

\footnotetext{
${ }^{1}$ Data were covariately adjusted with the least squares means for response variables measured at 1200 $\mathrm{h}$ on $\mathrm{d} 5$ postpartum. Treatments were applied at $0800 \mathrm{~h}$ on $\mathrm{d} 3$ postpartum.

${ }^{2}$ Probability values were Satterthwaite approximates. Contrasts: Insulin = cows intramuscularly injected with sterile water versus cows intramuscularly injected with slow-release insulin; Linear = linear effect of increasing doses of slow-release insulin; Quadratic = quadratic effect of increasing doses of slow-release insulin.
}

(Table 3). A high correlation between concentrations of plasma NEFA and liver TG $(\mathrm{r}=0.57, P<0.0008)$ suggests that until factors impeding hepatic VLDL-TG export are identified, limiting uptake of NEFA by the liver through the antilipolytic effect of insulin can be an important strategy to prevent development of hepatic lipidosis.

Liver glycogen. Glycogen was deposited in the liver during d 2 to 5 postpartum (Table 3). Although the amount of GLY deposited in the liver did not differ between CISRI and CISW $(P<0.44)$, increasing dose of SRI tended to quadratically increase the amount of GLY deposited $(P<0.14)$. However, on a percentage basis, changes in liver GLY concentration for CISRI and CISW during d 2 to 5 were not different $(P<0.75)$. On d 5 postpartum, there were no differences in GLY concentrations between CISRI and CISW $(P<0.41)$, but increasing dose of SRI tended to increase concentrations of GLY quadratically $(P<0.08)$.

In contrast to plasma glucose concentrations, increasing dose of SRI quadratically increased GLY deposition and GLY concentration (Table 3). Insulin suppresses activities of gluconeogenic enzymes (pyruvate carboxylase and phosphoenolpyruvate carboxykinase) (O'Brien and Granner, 1990), enhances activity of glycogen synthase that stimulates glycogenesis (Genuth, 1993), and inhibits activity of glycogen phosphorylase that stimulates glycogenolysis (Genuth, 1993) in the liver. In insulin-resistant monkeys, these enzymes responded to insulin in liver but not in muscle (Ortmeyer and Hansen, 1998), indicating that degree of resistance may vary among tissues, with the liver being a less resistant tissue.

In the present study, changes in liver GLY content were inversely related with changes in TG content $(r=$
$-0.55, P<0.0007)$. Although there were no differences in ratio of TG to GLY in the liver between CISRI and CISW $(P<0.47)$, increasing dose of SRI quadratically decreased the ratio of TG to GLY $(P<0.08$; Table 3$)$. Drackley et al. (1992) showed that liver function was impaired during induction of ketosis and suggested that the ratio of TG to GLY is a predictor of a cow's likelihood to develop ketosis.

\section{CONCLUSIONS}

This study was conducted to determine whether there is a dose of SRI that decreases plasma NEFA and liver TG, without decreasing plasma glucose concentration. There was no dose of SRI that did not cause hypoglycemia ( $<45 \mathrm{mg}$ glucose/dl). In fact, SRI had more dramatic effects on plasma glucose concentration than plasma NEFA concentrations. This suggests that immediately after parturition, lipolysis in adipose tissue is more resistant to effects of insulin than glucose metabolism in tissues such as the liver. However, the lowest dose of SRI increased DMI, milk yield, and concentrations of serum insulin and liver GLY and decreased the ratio of hepatic TG to GLY, hepatic TG, and plasma NEFA and BHBA. Many responses to insulin were quadratic, some of which may have been related (e.g., plasma NEFA and liver TG). Quadratic responses are difficult to explain but may be related to down regulation of receptors at highest doses of SRI. Administration of the low dose of SRI (0.14 IU/kg BW) could be considered as a prophylactic against hepatic lipidosis and ketosis during the periparturient period. In this study, the effects of SRI were monitored in healthy cows; effects of SRI in cows prone to lipid-related metabolic disorders need to be evaluated. 


\section{ACKNOWLEDGMENTS}

We thank the Turkish Government for partial financial support of Armagan Hayirli's educational expenses; Bob Elderbrook for feeding cows; Douglas Mashek, Claudia Leonardi, and Mathew Doshorst for helping to insert catheters; Euler Rabelo for performing liver biopsies; Erika Alderman-Macht for blood sampling; and Jessica Kayhart for laboratory analyses.

\section{REFERENCES}

Association of Official Analytical Chemists. 1990. Official Methods of Analysis. Vol. I. 15th ed. AOAC, Arlington, VA.

Baile, C. A., and J. Mayer. 1968. Effects of insulin-induced hypoglycemia and hypoacetonemia on eating behavior in goats. J. Dairy Sci. 51:1495-1499.

Ballard, F. J., R. W. Hanson, D. S. Kronfeld, and F. Raggi. 1968. Metabolic changes in liver associated with spontaneous ketosis and starvation in cows. J. Nutr. 95:160-173.

Bremmer, D. R., S. J. Bertics, S. A. Besong, and R. R. Grummer. 2000. Changes in hepatic microsomal triglyceride transfer protein in periparturient dairy cattle. J. Dairy Sci. 83:2252-2260.

Brockman, R. P. 1979. Roles for insulin and glucagon in the development of ruminant ketosis. Can. Vet. J. 20:121-126.

Brockman, R. P., and B. Laarveld. 1986. Hormonal regulation of metabolism in ruminants. Livest. Prod. Sci. 14:313-334.

Cadorniga-Valino, C., R. R. Grummer, L. E. Armentano, S. S. Donkin, and S. J. Bertics. 1997. Effects of fatty acids and hormones on fatty acid metabolism and gluconeogenesis in bovine hepatocytes. J. Dairy Sci. 80:646-656.

Carmer, S. G., and R. D. Seif. 1963. Calculation of orthogonal coefficients when treatments are unequally replicated and/or unequally spaced. Agron. J. 55:387-389.

Chirieac, D. V., L. R. Chirieac, J. P. Corsetti, J. Cianci, C. E. Sparks, and J. D. Sparks. 2000. Glucose-stimulated insulin secretion suppresses hepatic triglyceride-rich lipoprotein and apoB production. Am. J. Physiol. 279:E1003-E1011.

DeBoer, G., A. Trenkle, and J. W. Young. 1985. Glucagon, insulin, growth hormone, and some blood metabolites during energy restriction ketonemia of lactating cows. J. Dairy Sci. 68:326-337.

Deetz, L. E., and P. J. Wangsness. 1980. Effects of intrajugular administration of insulin on feed intake, plasma glucose and plasma insulin of sheep. J. Nutr. 110:1976-1982.

Deetz, L. E., and P. J. Wangsness. 1981. Influence of intrajugular administration of insulin, glucagon and propionate on voluntary feed intake of sheep. J. Anim. Sci. 53:427-433.

Deetz, L. E., P. J. Wangsness, J. F. Kavanaugh, and E. C. Griel, Jr. 1980. Effect of intraportal and continuous administration of insulin on feeding in sheep. J. Nutr. 110:1983-1991.

Drackley, J. K., M. J. Richard, D. C. Beitz, and J. W. Young. 1992 Metabolic changes in dairy cows with ketonemia in response to feed restriction and dietary 1,3-butanediol. J. Dairy Sci. 75:1622-1634.

Drug Facts and Comparisons. 2000. Lippincott, Williams, and Wilkens, Inc., Philadelphia, PA.

Fleming, S. A. 1990. Ketosis of ruminants (acetonemia). Pages 13061314 in Large Animal Internal Medicine. 2nd ed. B. P. Smith, ed. Mosby Co., St. Louis, MO.

Folch, J., M. Lees, and G. H. Sloane Stanley. 1957. A simple method for the isolation and purification of total lipids from animal tissues. J. Biol. Chem. 226:497-509.

Foster, L. B., and R. T. Dunn. 1973. Stable reagents for determination of serum triglycerides by a colorimetric hantzsch condensation method. Clin. Chem. 19:338-340.

Garvey, W. T., J. M. Olefsky, and S. Marshall. 1986. Insulin induces progressive insulin resistance in cultured rat adipocytes: Sequential effects at receptor and post-receptor cites. Diabetes $35: 258-267$.
Genuth, S. M. 1993. Hormones of the pancreatic islets. Pages 851875 in Physiology. 3rd ed. R. M. Berne and M. N. Levy, eds. Mosby Co., St. Louis, MO.

Gibbons, G. F. 1990. Assembly and secretion of hepatic very-low density lipoprotein. Biochem. J. 268:1-13.

Goth, A. 1968. Insulin and oral antidiabetic drugs. Pages 489-502 in Medical Pharmacology: Principles and Concepts. 4th ed. Mosby Co., St. Louis, MO.

Grantham, B. D., and V. A. Zammit. 1988. Role of carnitine palmitoyltransferase I in the regulation of hepatic ketogenesis during the onset and reversal of chronic diabetes. Biochem. J. 249:409-419.

Greenhouse, S. W., and S. Geisser. 1959. On methods in the analysis of profile data. Psychometrika 32:95-112.

Grummer, R. R. 1993. Etiology of lipid-related metabolic disorders in periparturient dairy cows. J. Dairy Sci. 76:3882-3896.

Hartwell, R. B., M. J. Cecava, T. R. Johnson, and S. S. Donkin. 2000. Impact of dietary protein amount and rumen undegradability on intake, peripartum liver triglyceride, plasma metabolites, and milk production in transition dairy cattle. J. Dairy Sci. 83:703710.

Hayirli, A., D. R. Bremmer, S. J. Bertics, M. T. Socha, and R. R. Grummer. 2001. Effect of chromium supplementation on production and metabolic parameters in periparturient dairy cows. J. Dairy Sci. 84:1218-1230.

Herbein, J. H., R. J. Aiello, L. I. Eckler, R. E. Pearson, and R. M. Akers. 1985. Glucagon, insulin, growth hormone, and glucose concentrations in plasma of lactating dairy cows. J. Dairy Sci. 68:320-325.

Holtenius, P. 1993. Hormonal regulation related to the development of fatty liver and ketosis. Acta. Vet. Scand. 89(S):55-60.

Hsu, W. H., and M. H. Crump. 1989. The endocrine pancreas. Pages 186-201 in Veterinary Endocrinology and Reproduction. 4th ed. L. E. McDonald, ed. Lea and Febiger Publishing Co., Philadelphia, PA.

Johnson, M. J., and J. P. Peters. 1993. Technical note: An improved method to quantify nonesterified fatty acids in bovine plasma. J. Anim. Sci. 71:753-756.

Katzung, B. G. 1995. Pancreatic hormones and antidiabetic drugs. Pages 637-654 in Basic and Clinical Pharmacology. 6th ed. Appleton and Lange Co., Norwalk, CT.

Kleppe, B. B., R. J. Aiello, R. R. Grummer, and L. E. Armentano. 1988. Triglyceride accumulation and very low density lipoprotein secretion by rat and goat hepatocytes in vitro. J. Dairy Sci. 71:1813-1822.

Kronfeld, D. S., G. P. Mayer, J. M. Robertson, and F. Raggi. 1963. Depression of milk secretion during insulin administration. J. Dairy Sci. 46:559-563.

Laarveld, B., D. A. Christensen, and R. P. Brockman. 1981. The effect of insulin on net metabolism of glucose by the bovine mammary gland. Endocrinology 108:2217-2221.

Labarca, C., and K. Paigen. 1980. A simple, rapid, and sensitive DNA assay procedure. Anal. Biochem. 102:344-352.

Littell, C. R., G. A. Milliken, W. W. Stroup, and F. D. Wolfinger. 1996. SAS System for Mixed Models. SAS Inst., Inc., Cary, NC.

Lo, S., J. C. Russell, and A. W. Taylor. 1970. Determination of glycogen in small tissue samples. J. Appl. Physiol. 28:234-236.

Mertens, D. R. 1999. Variation in aNDF results with modifications of the fiber bag method. Pages 1-7 in Proc. Natl. Forage Testing Assoc. Tech. Session Papers and Committee Reports to the Board and Membership, Topeka, KS.

National Research Council. 2001. Nutritional Requirements of Dairy Cattle. 7th rev. ed. Natl. Acad. Sci., Washington, DC.

O'Brien, R. M., and D. K. Granner. 1990. PEPCK gene as a model of inhibitory effects of insulin on gene transcription. Diabetes Care 13:327-334.

Ortmeyer, H. K., and B. C. Hansen. 1998. Lack of defect in insulin action on hepatic glycogen synthase and phosphorylase in insulinresistant monkeys. Am. J. Physiol. 274:G1005-G1010.

Pearson, E. G., and J. Maas. 1990. Hepatic lipidosis. Pages 860-866 in Large Animal Internal Medicine. 2nd ed. B. P. Smith, ed. Mosby Co., St. Louis, MO. 
Raabo, E., and T. C. Terkildsen. 1960. On the enzymatic determination of blood glucose. Scand. J. Clin. Lab. Invest. 12:402-407.

Reynolds, J. E. F. 1989. Insulin. Pages 391-398 in Martindale: The Extra Pharmacopoeia. 29th ed. The Pharmaceutical Press, London, UK.

Sakai, T., T. Hayakawa, M. Hamakawa, K. Ogura, and S. Kubo. 1993. Therapeutic effects of simultaneous use of glucose and insulin in ketotic dairy cows. J. Dairy Sci. 76:109-114.

Sano, H., M. Nakai, T. Kondo, and Y. Terashima. 1991. Insulin responsiveness to glucose and tissue responsiveness to insulin in lactating, pregnant, and nonpregnant, nonlactating beef cows. J. Anim. Sci. 69:1122-1127.

Sato, T., K. Taguchi, K. Nagao, and A. Matsumoto. 1986. Therapeutic use of insulin in diseases showing hyperlipoproteinemia in dairy cows. J. Vet. Clin. (Jpn). 273:5.

Satoh, S., S. Inoue, M. Egawa, Y. Takamura, and T. Murase. 1987. Insulin increases triglyceride secretion rate in rats in vivo. Int. J. Obesity. 11:325-331.

SAS User's Guide: Statistics, Version 7 Edition. 1998. SAS Inst., Inc. Cary, NC.
Schmidt, G. H. 1966. Effect of insulin on yield and composition of milk of dairy cows. J. Dairy Sci. 49:381-385.

Toyoda, Y., M. Nasu, K. Sakai, K. Shigematsu, and K. Watanabe. 1987. Effects of insulin therapy to hyperlipoproteinemia and fatty liver in dairy cows. J. Vet. Clin. (Jpn). 288:13.

Williamson, D. H., J. Mellanby, and H. A. Krebs. 1962. Enzymatic determination of $\mathrm{D}(-) \beta$-hydroxybutyric acid and acetoacetic acid in blood. Biochem. J. 82:90-99.

Vazquez-Anon, M., S. J. Bertics, M. Luck, and R. R. Grummer. 1994. Peripartum liver triglyceride and plasma metabolites. J. Dairy Sci. 77:1521-1528.

Van Epps-Fung, M., J. Williford, A. Wells, and R. W. Hardy. 1997. Fatty-acid induced insulin resistance adipocytes. Endocrinology 138:4338-4345.

Van Putten, J., P. T. Wieringa, and H. M. Krans. 1985. Low pH and ketoacidosis induce insulin receptor binding and postbinding alterations in cultured 3T3 adipocytes. Diabetes. 34:744-750.

Zammit, V. A. 1996. Role of insulin in hepatic fatty acid partitioning: Emerging concepts. Biochem. J. 314:1-14.

Zhao, F. Q., D. R. Gilmm, and J. J. Kennely. 1993. Distribution of mammalian facilitative glucose transporter messenger RNA in bovine tissues. Int. J. Biochem. 25:1897-1992. 